\title{
Bathymetrical and temporal variations in soft-bottom molluscan assemblages in the coastal area facing the Sarno River mouth (Mediterranean Sea, Gulf of Naples)
}

\author{
Luigia Donnarumma, Roberto Sandulli, Luca Appolloni*, Federica Ferrigno, Francesco Rendina, \\ Floriana Di Stefano, Giovanni Fulvio Russo
}

\begin{abstract}
Department of Science and Technology, Parthenope University of Naples, 80143 Naples, Italy; CoNISMa (National Interuniversity Consortium for Marine Sciences), 00196 Rome, Italy

*Corresponding author e-mail: luca.appolloni@uniparthenope.it
\end{abstract}

Received: 15 May 2020 / Accepted: 2 July 2020

\begin{abstract}
Molluscan assemblage of coastal area facing the very polluted Sarno River estuary to offshore (Gulf of Naples, Italy) was studied, focusing on temporal and depth-related distribution of species diversity, quali-quantitative composition and trophic guilds structure. A total of 9 stations, at depths ranging between 7 and $95 \mathrm{~m}$, were sampled in triplicate by means of a $0.17 \mathrm{~m}^{2}$ Van Veen grab in four sampling occasions ( 2 seasons, winter and summer, during 2 years, 2015 and 2016). A total of 1,744 individuals, belonging to 78 species and 3 classes (Bivalvia, Gastropoda and Scaphopoda), was recorded. Bivalves, followed by gastropods, qualitatively and quantitatively dominated the mollusc assemblages and both these taxonomic groups showed the highest values in the shallower stations down to about $25 \mathrm{~m}$ depth. In the deeper stations, only the bivalve taxon was dominant, even though exhibiting a much lower species richness and abundance. On the overall, the molluscan species were ascribed to 6 feeding guilds: Suspension and deposit feeders were the dominant trophic groups, occurring at all stations along the bathymetrical gradient, while predators, detritus feeders, ecto-parasites and scavengers were poorly represented and mainly occurred in the shallowest stations. The mollusc composition and distribution pattern along the bathymetrical gradient over time show signs of structural stability that might be mainly due to the continuous supply of organic matter from the river mouth expanding to all area. These results are of primary importance for filling the knowledge gaps on benthic biodiversity over a still poorly known and very fragile coastal area under continuous anthropogenic pressures mainly through the runoff of a very polluted river.
\end{abstract}

Keywords: Benthic assemblages, trophic guilds, sediments, pollution, coastal environment, Gulf of Naples.

\section{Introduction}

Estuarine environments and coastal areas in proximity of estuaries are peculiar coastal zones where benthic communities are strongly affected by salinity variations, nutrient loadings and sediment supply carried by river flows (Bevilacqua et al., 2012; Edgar and Barrett, 2002 and references therein; Herman et al., 1999; Semprucci et al., 2017, 2019). Rivers, especially those crossing the urbanized, industrial and agricultural areas, are vehicles of high loads of or- ganic and inorganic pollutants. In the estuarial areas, these contaminants may lead to anoxic waters or sediments, enriched by fertilizers and pesticides, derived from intense agriculture activities, with high concentrations of heavy metals coming from industrial processes. This is the case of the Sarno River, which flows into the Gulf of Naples, between Torre Annunziata and Castellammare di Stabia towns. This river is widely known as the most polluted in Europe and among the ten most polluted rivers in the world, due to its high concentration of inorganic and or- 
ganic pollutants (Cicchella et al., 2014; De Pippo et al., 2006; Melluso et al., 1994; Montuori et al., 2014, 2015). The latter group of contaminants is among the main factors influencing the ecological community structure and species distribution, especially in estuarine and shallow coastal waters (Boesch et al., 1976; Herman et al., 1999; Jickells, 1998). Several studies have also highlighted the role of the sediment particles size in driving macrobenthic community structure and zonation in estuarial environments under river flow regime (Mannino and Montagna, 1997; Meade, 1972; Miller et al., 2002; Teske and Wooldridge, 2003). Molluscs are an important taxonomic group of both rocky and soft bottom macrobenthic communities and are ecologically relevant in terms of natural capital accounting (Buonocore et al., 2018, 2019, 2020a,b) and environmental impact assessment, thanks to their relevant adaptive radiation, that includes many species to be cryptic and habitat formers primarily in the Mediterranean Sea (Casoli et al., 2019; Dimitriadis and Koutsoubas, 2008; Donnarumma et al., 2018a,b,c; Moraitis et al., 2018; Russo et al., 1985; Russo e Patti, 2005; Urra et al., 2011). Among molluscs, the infaunal species represented by sedentary deposit- and suspension-feeding bivalves, are considered key components in monitoring and assessment of environmental quality of soft-bottom ecosystems (Dame, 2016). This is due to strong interaction between bivalves and sediment, from which deposit feeders extract organic particles as food, and suspension feeders filter the overlying water column at sediment-water interface.

Sediment and water contaminantion of coastal area in proximity to the Sarno River has been previously reported (Griggs and Johnson, 1978; Montuori et al., 2014, 2015), but to date little information is available about macrobenthic communities occurring in the coastal area next to the Sarno estuary. The aims of the present study are, therefore, (i) to investigate the structure and bathymetrical distribution of the mollusc assemblages along a depth gradient from the mouth of the Sarno River to offshore; (ii) to analyze temporal variations of the mollusc assemblages in terms of species composition and trophic structure.

\section{Materials and methods}

\subsection{Study areas and Sampling design}

The study was carried out in the coastal area facing the estuary of Sarno River, which is located in the Gulf of Naples, between Torre Annunziata and Castellammare di Stabia (4043'42'N-14'37'42'E) towns. A total of 9 sampling stations were located along the depth gradient from the estuary (station A: $7 \mathrm{~m}$ depth, $0.5 \mathrm{~km}$ of distance; B: $17 \mathrm{~m}, 0.9 \mathrm{~km}$; C: $24 \mathrm{~m}, 1.23 \mathrm{~km}$; D: $37 \mathrm{~m}, 1.87 \mathrm{~km}$; E: 47m, 2.72km; F: 56m, 3.41km; G: 70m, 4.93km; H:
$85 \mathrm{~m}, 6.36 \mathrm{~km}$; I: $95 \mathrm{~m}, 7.45 \mathrm{~km}$ ) along a transect orthogonal to the coast (Figure 1). Sediment samples were collected at each station with three replicates, in two seasons (Winter [W] and Summer [S]), during two years (2015 and 2016). The soft sediment and associated benthic fauna were collected using a $0.17 \mathrm{~m}^{2}$ Van Veen grab. Tthe sediment samples were sieved through a $0.5 \mathrm{~mm}$ mesh and then fixed in $4 \%$ formalin-seawater solution. In the laboratory, under a stereomicroscope, molluscs were selected and identified at the lowest possible taxonomic level. Mollusc nomenclature followed the World Register of Marine Species database (WoRMS, 2020).

\subsection{Data analysis}

Descriptive analyses were performed on cumulated triplicates for each station. Ecological indices, i.e. abundance $\left(\mathrm{N}=\mathrm{n} . \mathrm{ind} / 0.17 \mathrm{~m}^{2}\right)$, species richness $(\mathrm{S})$, Shannon-Wiener diversity index (H') and Pielou evenness (J), were calculated for the mollusc assemblages in the samples. The quantitative and qualitative dominances (\%ID and \%QD, respectively) were also computed. Regarding functional criteria, the feeding guilds were assigned to each species on the basis of its food assumption mode, according to Allen (1958), Purchon (1977), Hughes (1986), Fish and Fish (1989) and Dame (2016). The following guilds were considered: Predators (P), feeding on sedentary or motile animals; Ectoparasites (E), feeding on the outside of much larger animals; Scavengers (SC), feeding on dead animals; Detritus feeders (DtF), herbivores feeding on both diatoms and/or microalgae scraped from sandy grains; Suspension (SF) and Deposit (DpF) feeders, feeding on organic particles which are suspended in sediment-water interface and deposited on the bottom, respectively.

To evaluate differences between sampling stations along the depth gradient and time, PERMANOVA analysis was performed. A three-way model was used with year (2 levels, 2015 vs. 2016), season (2 levels, winter vs. summer, nested in year) and depth (9 levels/stations, nested in season and year) as fixed factors. Data were transformed using $\log (\mathrm{x}+1)($ Clarke and Warwick, 2001) to reduce the effect of dominant taxa in the samples and 9999 permutations of the raw data units were computed. The structure of mollusc assemblages was investigated using canonical analysis of principal coordinates (CAP) and hierarchical cluster analysis, based on the Bray-Curtis similarity. Multivariate analyses were performed using the PRIMERPERMANOVA+v.6 software package (Anderson et al., 2008; Clarke and Gorley, 2006). 


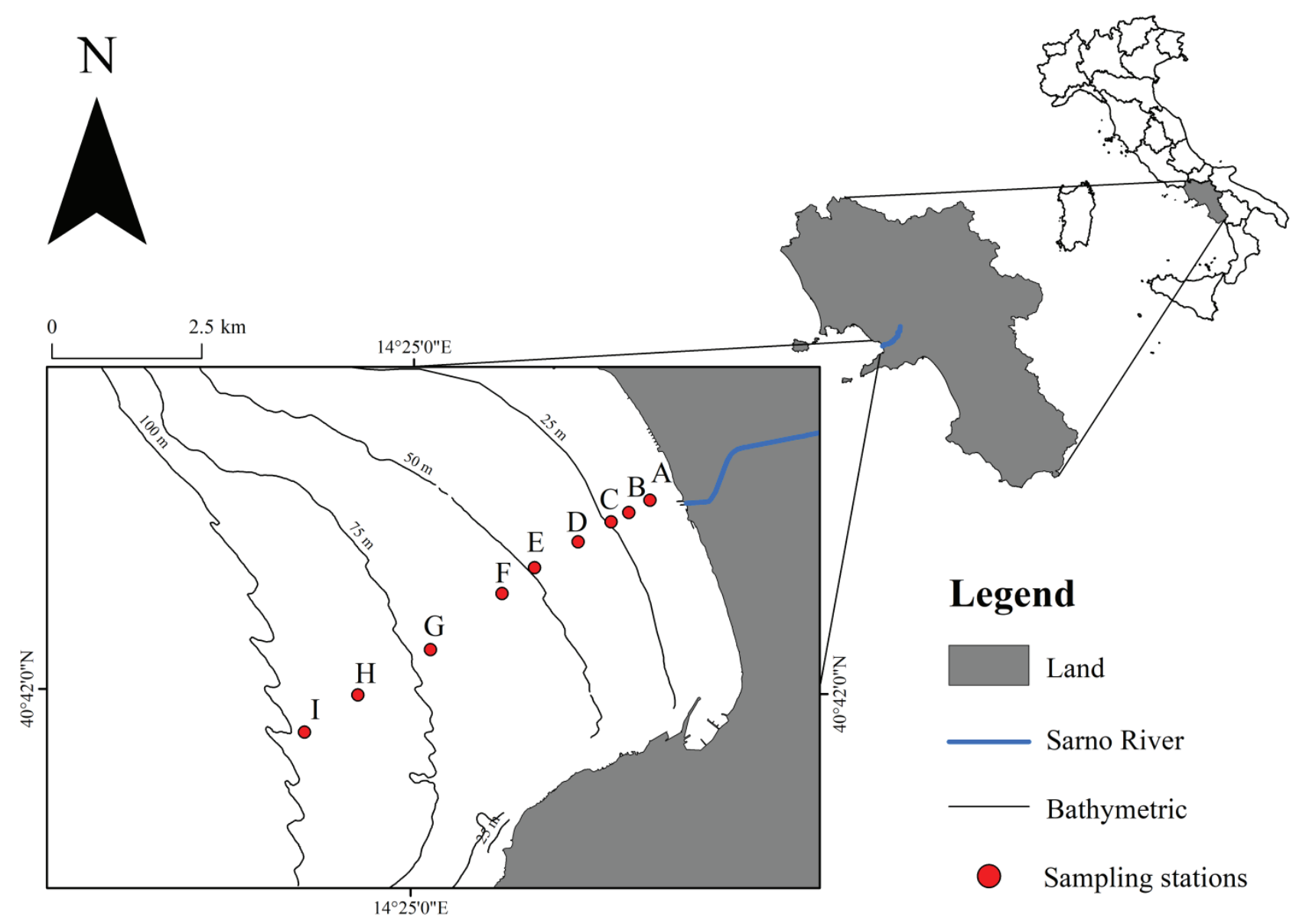

Figure 1. Map of the study area with location of the investigated stations (A - I) along the depth gradient, from the coastal area facing to the estuary of Sarno River to offshore.

\section{Results}

\subsection{Composition of mollusc assemblages and bathymetrical and temporal variations}

A total of 1,744 molluscs, belonging to 78 species and 3 classes (Bivalvia, Gastropoda and Scaphopoda), was recorded in the study area during four sampling times (Table 1).

Bivalves were the most abundant taxonomic group and were dominant both in number of species (49 species; $62.82 \%$ ) and individuals (1562 ind.; 89.56\%). Just 5 species of bivalves contributed for more than $65 \%$ of abundance: Lucinella divaricata (Linnaeus, 1758) (292 individuals; $18.69 \%$ of total bivalves), Spisula subtruncata (da Costa, 1778) (233; 14.92\%), Thyasira biplicata (Philippi, 1836) (230; 14.72\%), Axinulus alleni (Carrozza, 1981) (172; 11.01\%) and Loripes orbiculatus Poli, 1795 (113; $7.23 \%$ ). Gastropods were the second group, with a total of 28 species (35.90\%) and 181 individuals (10.38\%).
Within this group, the 4 most common species reached about $50 \%$ of abundance: Turritellinella tricarinata (Brocchi, 1814) (25 ind.; 13.81\%), Tritia varicosa (W. Turton, 1825) (20 ind.; 11.05\%), Bela nebula (Montagu, 1803) (24 ind.; 13.26\%) and Hyala vitrea (Montagu, 1803) (17 ind.; 9.39\%). Scaphopods were the last taxonomic group, represented by only one individual belonging to the species Fustiaria rubescens (Deshayes, 1826).

Moving from shallow to deeper stations, mollusc abundance and species richness decreased and quite similar dominances between seasons and years were observed at each station, both for bivalves and gastropods (Figure 2).

The shallower stations $\mathrm{A}, \mathrm{B}$ and $\mathrm{C}$, ranging between 7 and 25 meters depth, showed high quantitative (ID: 75\% [1168 ind.], Figure 2a) and qualitative (QD: 53\% [36 sp.], Figure 2b) dominances of bivalves. L. divaricata was dominant in winter (W2015: 24\% (73ind.) - W2016: 34\% (100 ind.)), followed by $T$. biplicata (W2015: 11\% (35 ind.) - W2016: 27\% (80 ind.)); in summer S. subtruncata was dominant (S2015: 42\% (158ind.) - S2016: 
Table 1. List of mollusc species with their feeding guilds (FG: Predators (P), Ectoparasites (E), Scavengers (SC), Detritus feeders (DtF), Suspension feeders (SF), Deposit feeders (DpF)), total number of individuals (Nt) and quantitative dominance of specie (\%ID) on each class, for each sampling time (W15 - winter 2015; S15 - summer 2015; W16 - winter 2016; S16 - summer 2016)

\begin{tabular}{|c|c|c|c|c|c|c|c|c|c|}
\hline \multirow[b]{2}{*}{ FG } & \multirow[b]{2}{*}{ Species } & \multicolumn{2}{|c|}{ W15 } & \multicolumn{2}{|c|}{ S15 } & \multicolumn{2}{|c|}{ W16 } & \multicolumn{2}{|c|}{ S16 } \\
\hline & & $\mathrm{Nt}$ & ID \% & $\mathbf{N t}$ & ID\% & $\mathbf{N t}$ & ID \% & Nt & ID\% \\
\hline \multirow{3}{*}{$\mathrm{DpF}$} & Scaphopoda & & & & & & & & \\
\hline & Fustiaria rubescens (Deshayes, 1826) & - & - & - & - & 1 & 100 & - & - \\
\hline & Gastropoda & & & & & & & & \\
\hline $\mathrm{P}$ & Acteon tornatilis (Linnaeus, 1758) & - & - & 1 & 3.13 & 4 & 6.67 & 1 & 4.35 \\
\hline $\mathrm{P}$ & Bela menkhorsti van Aartsen, 1988 & - & - & - & - & 1 & 1.67 & - & - \\
\hline $\mathrm{P}$ & Bela nebula (Montagu, 1803) & 9 & 13.64 & 5 & 15.63 & 6 & 10 & 4 & 17.39 \\
\hline $\mathrm{DtF}$ & Bittium reticulatum (da Costa, 1778) & 2 & 3.03 & - & - & - & - & - & - \\
\hline $\mathrm{P}$ & Bolinus brandaris (Linnaeus, 1758) & - & - & 1 & 3.13 & 1 & 1.67 & - & - \\
\hline $\mathrm{E}$ & Chrysallida sp. & 1 & 1.52 & - & - & - & - & - & - \\
\hline $\mathrm{P}$ & Cylichna cylindracea (Pennant, 1777) & 5 & 7.58 & - & - & 1 & 1.67 & - & - \\
\hline $\mathrm{E}$ & Eulima glabra (da Costa, 1778) & 1 & 1.52 & - & - & - & - & - & - \\
\hline $\mathrm{P}$ & Euspira macilenta (Philippi, 1844) & - & - & 1 & 3.13 & 1 & 1.67 & 1 & 4.35 \\
\hline $\mathrm{P}$ & Euspira nitida (Donovan, 1804) & - & - & - & - & - & - & 1 & 4.35 \\
\hline $\mathrm{DtF}$ & Hyala vitrea (Montagu, 1803) & 9 & 13.64 & 5 & 15.63 & 2 & 3.33 & 1 & 4.35 \\
\hline $\mathrm{P}$ & Mangelia attenuata (Montagu, 1803) & 3 & 4.55 & - & - & - & - & - & - \\
\hline $\mathrm{P}$ & Mangelia costulata Risso, 1826 & 10 & 15.15 & - & - & 4 & 6.67 & 2 & 8.70 \\
\hline $\mathrm{P}$ & Mangelia scabrida Monterosato, 1890 & 1 & 1.52 & 6 & 18.75 & 5 & 8.33 & 3 & 13.04 \\
\hline $\mathrm{E}$ & Megastomia conoidea (Brocchi, 1814) & 1 & 1.52 & 1 & 3.13 & 1 & 1.67 & - & - \\
\hline $\mathrm{P}$ & Naticarius stercusmuscarum (Gmelin, 1791) & 1 & 1.52 & - & - & 1 & 1.67 & - & - \\
\hline $\mathrm{P}$ & Neverita josephinia Risso, 1826 & 2 & 3.03 & - & - & 1 & 1.67 & - & - \\
\hline $\mathrm{E}$ & Parthenina cf interstincta (J. Adams, 1797) & 1 & 1.52 & - & - & - & - & - & - \\
\hline $\mathrm{P}$ & Philine sp. & - & - & - & - & - & - & 1 & 4.35 \\
\hline $\mathrm{P}$ & Sorgenfreispira brachystoma (Philippi, 1844) & 7 & 10.61 & 2 & 6.25 & 5 & 8.33 & 1 & 4.35 \\
\hline $\mathrm{P}$ & Tectonatica sagraiana (d’Orbigny, 1842) & - & - & 1 & 3.13 & 1 & 1.67 & - & - \\
\hline $\mathrm{SC}$ & Tritia incrassata (Strøm, 1768) & - & - & 2 & 6.25 & - & - & - & - \\
\hline $\mathrm{SC}$ & Tritia mutabilis (Linnaeus, 1758) & 2 & 3.03 & 1 & 3.13 & 1 & 1.67 & 2 & 8.70 \\
\hline $\mathrm{SC}$ & Tritia varicosa (W. Turton, 1825) & 9 & 13.64 & - & - & 7 & 11.67 & 4 & 17.39 \\
\hline $\mathrm{P}$ & Trophonopsis muricata (Montagu, 1803) & - & - & - & - & - & - & 1 & 4.35 \\
\hline $\mathrm{E}$ & Turbonilla acutissima Monterosato, 1884 & 1 & 1.52 & - & - & - & - & - & - \\
\hline $\mathrm{E}$ & $\begin{array}{l}\text { Turbonilla gradata Bucquoy, Dautzenberg \& } \\
\text { Dollfus, } 1883\end{array}$ & 1 & 1.52 & - & - & - & - & - & - \\
\hline SF & Turritellinella tricarinata (Brocchi, 1814) & - & - & 6 & 18.75 & 18 & 30 & 1 & 4.35 \\
\hline
\end{tabular}




\begin{tabular}{|c|c|c|c|c|c|c|c|c|c|}
\hline \multirow[b]{2}{*}{ FG } & \multirow[b]{2}{*}{ Species } & \multicolumn{2}{|c|}{ W15 } & \multicolumn{2}{|c|}{ S15 } & \multicolumn{2}{|c|}{ W16 } & \multicolumn{2}{|c|}{ S16 } \\
\hline & & $\mathbf{N t}$ & ID \% & $\mathbf{N t}$ & ID\% & Nt & ID\% & $\mathbf{N t}$ & ID\% \\
\hline & Bivalvia & & & & & & & & \\
\hline $\mathrm{DpF}$ & Abra alba (W. Wood, 1802) & - & - & 2 & 0.44 & 2 & 0.50 & - & - \\
\hline $\mathrm{DpF}$ & Abra prismatica (Montagu, 1808) & - & - & - & - & - & - & 1 & 0.34 \\
\hline $\mathrm{SF}$ & Acanthocardia aculeata (Linnaeus, 1758) & - & - & 1 & 0.22 & - & - & - & - \\
\hline SF & $\begin{array}{l}\text { Acanthocardia paucicostata (G. B. Sowerby II, } \\
\text { 1834) }\end{array}$ & - & - & 2 & 0.44 & - & - & - & - \\
\hline $\mathrm{SF}$ & Acanthocardia tuberculata (Linnaeus, 1758) & - & - & - & - & - & - & 1 & 0.34 \\
\hline SF & Axinulus alleni (Carrozza, 1981) & 58 & 14.11 & 26 & 5.74 & 42 & 10.50 & 46 & 15.44 \\
\hline $\mathrm{SF}$ & Axinulus cf croulinensis (Jeffreys, 1847) & 1 & 0.24 & - & - & - & - & - & - \\
\hline $\mathrm{SF}$ & Azorinus chamasolen (da Costa, 1778) & 1 & 0.24 & - & - & - & - & - & - \\
\hline $\mathrm{SF}$ & Chamelea gallina (Linnaeus, 1758) & 7 & 1.70 & 7 & 1.55 & 2 & 0.50 & 4 & 1.34 \\
\hline $\mathrm{SF}$ & Corbula gibba (Olivi, 1792) & 6 & 1.46 & 2 & 0.44 & 6 & 1.50 & 2 & 0.67 \\
\hline $\mathrm{SF}$ & Ctena decussata (O. G. Costa, 1829) & - & - & 3 & 0.66 & 2 & 0.50 & 6 & 2.01 \\
\hline $\mathrm{SF}$ & Cuspidaria cuspidata (Olivi, 1792) & 2 & 0.49 & - & - & 1 & 0.25 & - & - \\
\hline $\mathrm{SF}$ & Cuspidaria rostrata (Spengler, 1793) & - & - & - & - & 1 & 0.25 & - & - \\
\hline $\mathrm{SF}$ & Dosinia exoleta (Linnaeus, 1758) & - & - & - & - & 1 & 0.25 & - & - \\
\hline $\mathrm{SF}$ & Dosinia lupinus (Linnaeus, 1758) & 8 & 1.95 & 2 & 0.44 & 1 & 0.25 & - & - \\
\hline $\mathrm{SF}$ & Ensis ensis (Linnaeus, 1758) & - & - & 3 & 0.66 & - & - & - & - \\
\hline $\mathrm{DpF}$ & Fabulina fabula (Gmelin, 1791) & 39 & 9.49 & 3 & 0.66 & 8 & 2 & 4 & 1.34 \\
\hline $\mathrm{SF}$ & Kelliella miliaris (Philippi, 1844) & - & - & 1 & 0.22 & 2 & 0.50 & - & - \\
\hline $\mathrm{SF}$ & Kurtiella bidentata (Montagu, 1803) & 1 & 0.24 & 4 & 0.88 & - & - & - & - \\
\hline $\mathrm{SF}$ & Loripes orbiculatus Poli, 1795 & 56 & 13.63 & 30 & 6.62 & 14 & 3.50 & 13 & 4.36 \\
\hline $\mathrm{SF}$ & Loripinus fragilis (Philippi, 1836) & 3 & 0.73 & 9 & 1.99 & 9 & 2.25 & 7 & 2.35 \\
\hline $\mathrm{SF}$ & Lucinella divaricata (Linnaeus, 1758) & 74 & 18 & 77 & 17 & 100 & 25 & 41 & 13.76 \\
\hline $\mathrm{SF}$ & Mactra stultorum (Linnaeus, 1758) & - & - & - & - & - & - & 1 & 0.34 \\
\hline $\mathrm{SF}$ & Mendicula ferruginosa (Forbes, 1844) & - & - & - & - & - & - & 2 & 0.67 \\
\hline $\mathrm{DpF}$ & Moerella cf pulchella (Lamarck, 1818) & 3 & 0.73 & 1 & 0.22 & - & - & 1 & 0.34 \\
\hline $\mathrm{DpF}$ & Moerella distorta (Poli, 1791) & 2 & 0.49 & 17 & 3.75 & 4 & 1 & 3 & 1.01 \\
\hline $\mathrm{DpF}$ & Moerella donacina (Linnaeus, 1758) & 25 & 6.08 & 1 & 0.22 & - & - & 3 & 1.01 \\
\hline $\mathrm{SF}$ & Myrtea spinifera (Montagu, 1803) & 14 & 3.41 & 7 & 1.55 & 14 & 3.50 & 14 & 4.70 \\
\hline $\mathrm{DpF}$ & Nucula nitidosa Winckworth, 1930 & 4 & 0.97 & 9 & 1.99 & 18 & 4.50 & 8 & 2.68 \\
\hline $\mathrm{DpF}$ & Nucula sulcata Bronn, 1831 & 8 & 1.95 & 9 & 1.99 & 10 & 2.50 & 5 & 1.68 \\
\hline $\mathrm{SF}$ & Papillicardium minimum (Philippi, 1836) & 3 & 0.73 & - & - & - & - & 1 & 0.34 \\
\hline SF & Parvicardium exiguum (Gmelin, 1791) & - & - & 1 & 0.22 & - & - & - & - \\
\hline
\end{tabular}




\begin{tabular}{|c|c|c|c|c|c|c|c|c|c|}
\hline \multirow[b]{2}{*}{ FG } & \multirow[b]{2}{*}{ Species } & \multicolumn{2}{|c|}{ W15 } & \multicolumn{2}{|c|}{ S15 } & \multicolumn{2}{|c|}{ W16 } & \multicolumn{2}{|c|}{ S16 } \\
\hline & & $\mathbf{N t}$ & ID\% & $\mathbf{N t}$ & ID\% & Nt & ID\% & $\mathbf{N t}$ & ID\% \\
\hline $\mathrm{DpF}$ & Peronaea planata (Linnaeus, 1758) & 7 & 1.70 & - & - & - & - & - & - \\
\hline $\mathrm{DpF}$ & Peronidia albicans (Gmelin, 1791) & 9 & 2.19 & 5 & 1.10 & 17 & 4.25 & 3 & 1.01 \\
\hline $\mathrm{SF}$ & Pharus legumen (Linnaeus, 1758) & 2 & 0.49 & 4 & 0.88 & 6 & 1.50 & 1 & 0.34 \\
\hline $\mathrm{SF}$ & Phaxas pellucidus (Pennant, 1777) & - & - & - & - & - & - & 1 & 0.34 \\
\hline $\mathrm{SF}$ & Pitar rudis (Poli, 1795) & 3 & 0.73 & - & - & - & - & - & - \\
\hline $\mathrm{SF}$ & Polititapes aureus (Gmelin, 1791) & 1 & 0.24 & - & - & - & - & - & - \\
\hline $\mathrm{DpF}$ & Saccella commutata (Philippi, 1844) & 6 & 1.46 & 1 & 0.22 & 7 & 1.75 & 8 & 2.68 \\
\hline $\mathrm{DpF}$ & Serratina serrata (Brocchi, 1814) & 4 & 0.97 & 7 & 1.55 & 3 & 0.75 & 6 & 2.01 \\
\hline $\mathrm{DpF}$ & Solemya togata (Poli, 1791) & - & - & - & - & 1 & 0.25 & 1 & 0.34 \\
\hline $\mathrm{SF}$ & Spisula subtruncata (da Costa, 1778) & 5 & 1.22 & 158 & 34.88 & 23 & 5.75 & 47 & 15.77 \\
\hline $\mathrm{SF}$ & Tellimya ferruginosa (Montagu, 1808) & 1 & 0.24 & 2 & 0.44 & 1 & 0.25 & 2 & 0.67 \\
\hline $\mathrm{SF}$ & Thracia phaseolina (Lamarck, 1818) & - & - & 11 & 2.43 & - & - & - & - \\
\hline $\mathrm{SF}$ & Thracia villosiuscula (MacGillivray, 1827) & 5 & 1.22 & 1 & 0.22 & 5 & 1.25 & 30 & 10.07 \\
\hline $\mathrm{SF}$ & Thyasira biplicata (Philippi, 1836) & 48 & 11.68 & 47 & 10.38 & 99 & 24.75 & 36 & 12.08 \\
\hline SF & Thyasira flexuosa (Montagu, 1803) & 4 & 0.97 & - & - & - & - & - & - \\
\hline $\mathrm{SF}$ & Thyasira granulosa (Monterosato, 1874) & - & - & - & - & 1 & 0.25 & - & - \\
\hline $\mathrm{SF}$ & Tropidomya abbreviata (Forbes, 1843) & 1 & 0.24 & - & - & - & - & - & - \\
\hline
\end{tabular}

24\% (47 ind.)), followed by L. divaricata (S2015: 20\% (77 ind.) - S2016: 21\% (41 ind.)). In the 6 deeper stations (D-I), bivalves reached $25 \%$ of ID (394 ind.) and $47 \%$ of QD (21 sp.), and A. alleni showed the highest dominance, both in winter and summer (W2015: 51\% (54 ind.) W2016: 39\% (42 ind.) / S2015: 34\% (26 ind.) - S2016: 39\% (41 ind.).

Gastropods they mainly occurred at shallowest stations A and B (Figure 2a,b), ranging between 7 and 20 meters depth, where $76 \%$ of ID (139 ind.) and $68 \%$ of QD (23 sp.) were recorded. In winter 2015, Mangelia costulata Risso, 1826 (17\%, 10 ind.), B. nebula and T. varicosa (16\%, 9 ind. for both species) were the dominant gastropods, while in summer 2015, Mangelia scabrida Monterosato, 1890 and $B$. nebula were dominant (28\% (5ind.) for both species). Both in winter and summer 2016, T. varicosa and $B$. nebula were dominant [W2016: 18\% (7ind.) and 16\% (6 ind.) respectively; S2016: 21\% (4ind.) for both species]. In the remaining 7 deeper stations $(\mathrm{C}-\mathrm{I})$ gastropods were more scarce than in the shallower stations, reaching $24 \%$ of ID (42 ind.) and 32\% of QD (10 sp.) and H. vitrea was the only species occurring at the four sampling times.
The highest values of the structural community parameters, i.e. $\mathrm{N}, \mathrm{S}$ and $\mathrm{J}$, occurred at the shallowest stations $\mathrm{A}$ and $\mathrm{B}$ (Table2) and then they sharp decreased from station $\mathrm{C}$ to I. Shannon-Wiener diversity index (H') was quite constant at all stations.

\subsection{Trophic guilds diversity}

Along the bathymetric gradient, the molluscan species were ascribed to 6 feeding guilds (Figure 3). Suspension feeders occurred with the highest dominance of individuals and species richness throughout the depth gradient, reaching $75 \%$ of ID and $47 \%$ of QD totally. Deposit feeders were less represented, occurring throughout the depth gradient with $16 \%$ of ID and $18 \%$ of QD. The other 4 feeding guilds (DtF, E, P and SC) reached totally $9 \%$ of ID and $35 \%$ of $\mathrm{QD}$, mainly occurring in the shallowest stations (A-C). 

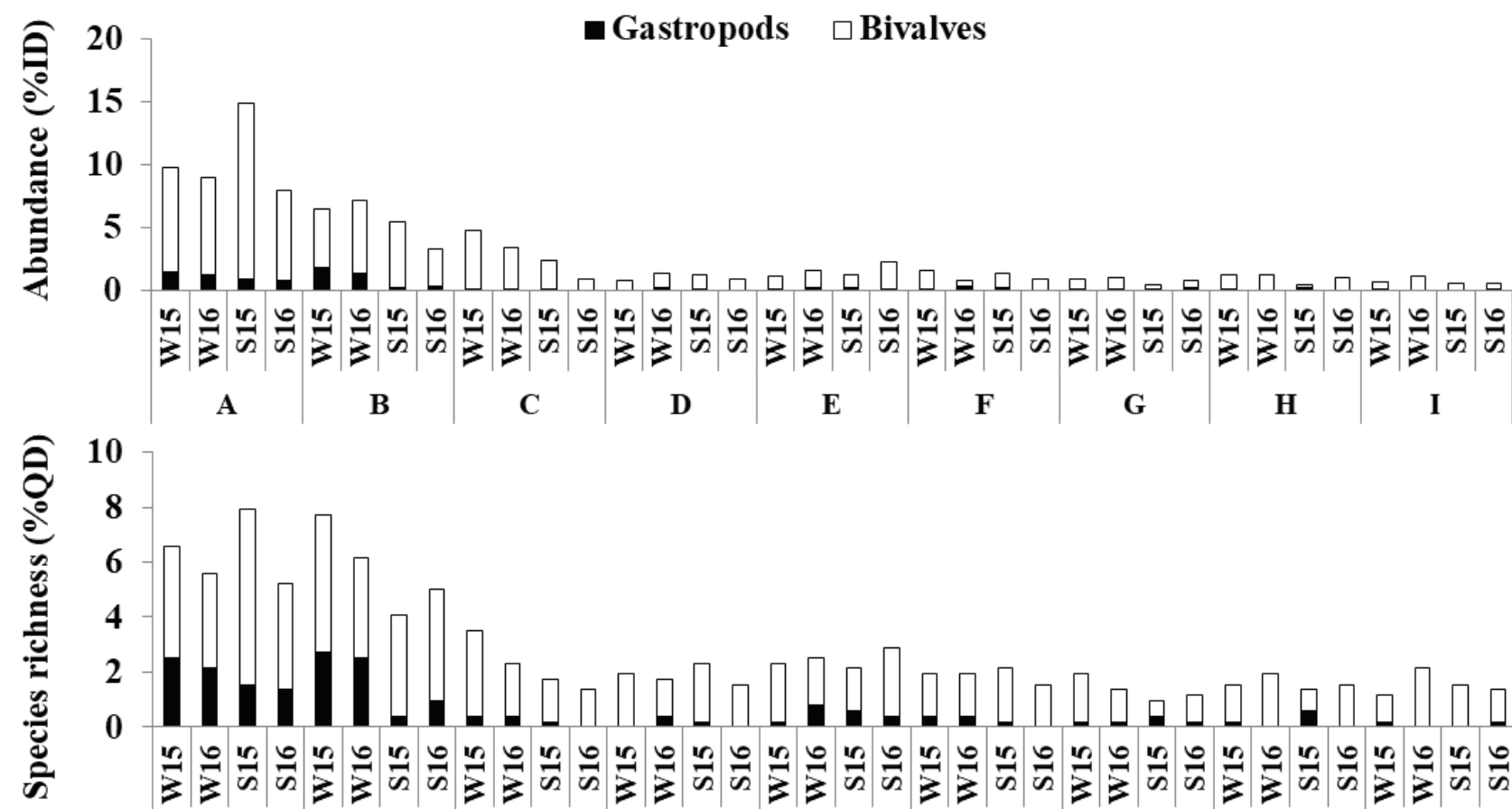

$$
\begin{array}{r}
10 \\
8 \\
6 \\
4 \\
2 \\
0
\end{array}
$$

$\mathbf{E}$

F

G

$\mathbf{H}$

I

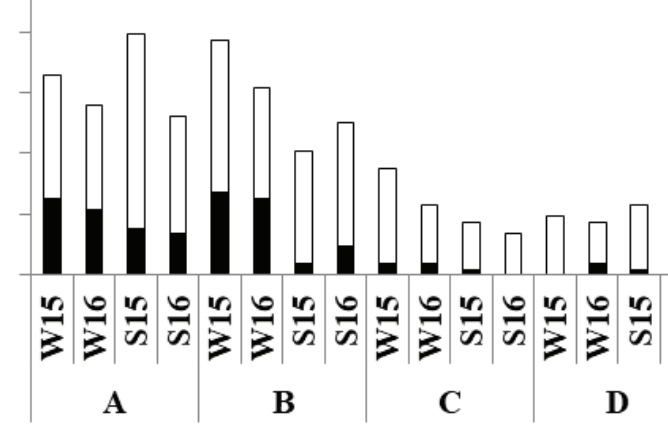

\section{Stations}

Figure 2. Temporal variations (years [2015-2016] and seasons [Winter W - Summer S]) of Abundance (\%ID) and Species richness (\%QD) of molluscs for each sampling station (A-I, cumulated triplicates).

Table 2. Mean values ( $\pm \mathrm{SD})$ on temporal data of structural community parameters $\left(\mathrm{S} ; \mathrm{N} ; \mathrm{H}^{\prime} ; \mathrm{J}\right)$ at each station and depth.

\begin{tabular}{cccccc}
\hline $\begin{array}{c}\text { Depth } \\
(\mathbf{m})\end{array}$ & Stations & $\mathbf{S}$ & $\mathbf{N}$ & $\mathbf{H} \mathbf{~}$ & $\mathbf{J}$ \\
\hline $7.7 \pm 2.5$ & $\mathrm{~A}$ & $11 \pm 2.02$ & $60.5 \pm 17.95$ & $0.69 \pm 0.13$ & $2.27 \pm 0.49$ \\
$18 \pm 2.6$ & $\mathrm{~B}$ & $9.83 \pm 2.78$ & $32.33 \pm 9.94$ & $0.83 \pm 0.09$ & $2.60 \pm 0.56$ \\
$23.7 \pm 3.8$ & $\mathrm{C}$ & $3.83 \pm 1.60$ & $16.5 \pm 9.57$ & $0.77 \pm 0.10$ & $1.24 \pm 0.41$ \\
$36.7 \pm 4.2$ & $\mathrm{D}$ & $3.25 \pm 0.57$ & $6 \pm 1.59$ & $0.88 \pm 0.07$ & $1.37 \pm 0.26$ \\
$47.3 \pm 0.6$ & $\mathrm{E}$ & $4.25 \pm 0.57$ & $8.92 \pm 2.91$ & $0.89 \pm 0.07$ & $1.78 \pm 0.13$ \\
$56 \pm 1$ & $\mathrm{~F}$ & $3.33 \pm 0.27$ & $6.75 \pm 2.31$ & $0.86 \pm 0.081$ & $1.44 \pm 0.19$ \\
70 & $\mathrm{G}$ & $2.33 \pm 0.72$ & $4.5 \pm 1.50$ & $0.89 \pm 0.10$ & $0.93 \pm 0.47$ \\
$85 \pm 1$ & $\mathrm{H}$ & $2.83 \pm 0.43$ & $5.75 \pm 2.44$ & $0.90 \pm 0.07$ & $1.30 \pm 0.15$ \\
$95.7 \pm 1.2$ & $\mathrm{I}$ & $2.6 \pm 0.72$ & $4.08 \pm 1.57$ & $0.89 \pm 0.09$ & $1.1 \pm 0.4$ \\
\hline
\end{tabular}

\subsection{Structural analysis}

The results of PERMANOVA revealed significant differences in the structure of mollusc assemblages only in response to the depth factor (Table 3), whilst variations across time (seasons, years) were not significant. Such results were confirmed by the cluster analysis: the dendrogram shows the groups of stations plotted coherently to their location along the bathymetrical gradient (Figure 4). Similarly, in the ordination model obtained by the CAP 

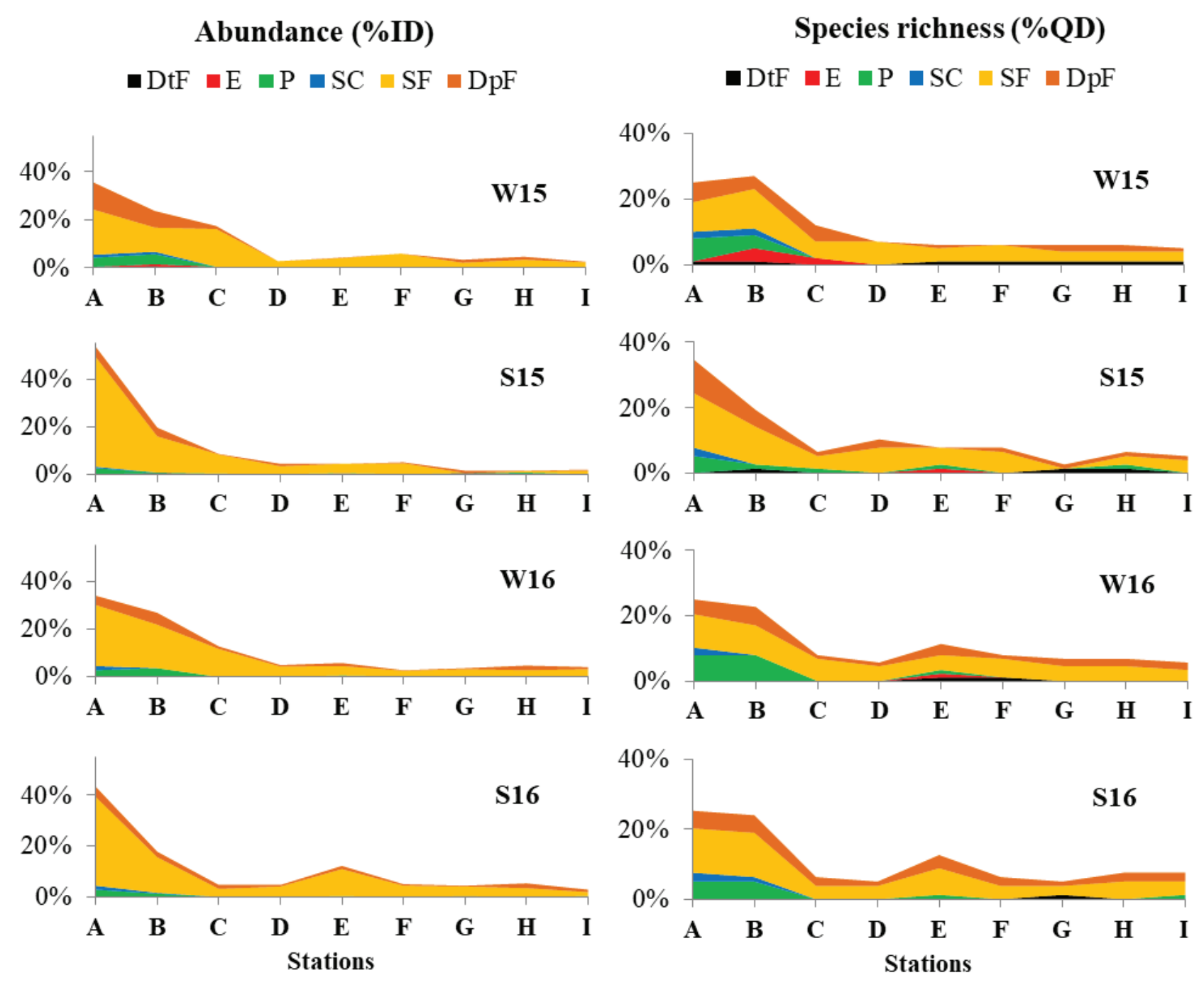

Figure 3. Feeding guilds (DtF Detritus feeders, E Ectoparasites, P Predators, SC Scavengers, SF Suspension feeders, DpF Deposit feeders) percent contribution to quantitative (ID) and qualitative (QD) dominances for each sampling station (A-I, cumulated triplicates) and time (W15 - winter 2015; S15 - summer 2015; W16 - winter 2016; S16 - summer 2016).

Table 3. Results of PERMANOVA with respect to the year (2 levels: 2015 vs. 2016), season (2 levels, winter vs. summer) and depth (9 levels/stations) variations of the structure of mollusc assemblages, considering the $p(\mathrm{MC})[p$-value calculated using the MonteCarlo permutation procedure].

\begin{tabular}{lccccccc}
\hline \multicolumn{1}{c}{ Factors } & df & SS & MS & $\boldsymbol{p s e u d o - F}$ & $\boldsymbol{p}$ (perm) & Unique perms & $\boldsymbol{p}(\mathbf{M C})$ \\
\hline Year & 1 & 3663.9 & 3663.9 & 1.7578 & 0.0736 & 4977 & 0.0966 \\
Season (Year) & 2 & 3823.4 & 1911.7 & 0.91714 & 0.5088 & 4973 & 0.5008 \\
Depth (Season (Year)) & 32 & $2.0876 \mathrm{E} 5$ & 6523.7 & 3.1298 & 0.0002 & 4917 & 0.0002 \\
Residual & 72 & $1.5008 \mathrm{E} 5$ & 2084.4 & & & & \\
Total & 107 & $3.6616 \mathrm{E} 5$ & & & & & \\
\hline
\end{tabular}




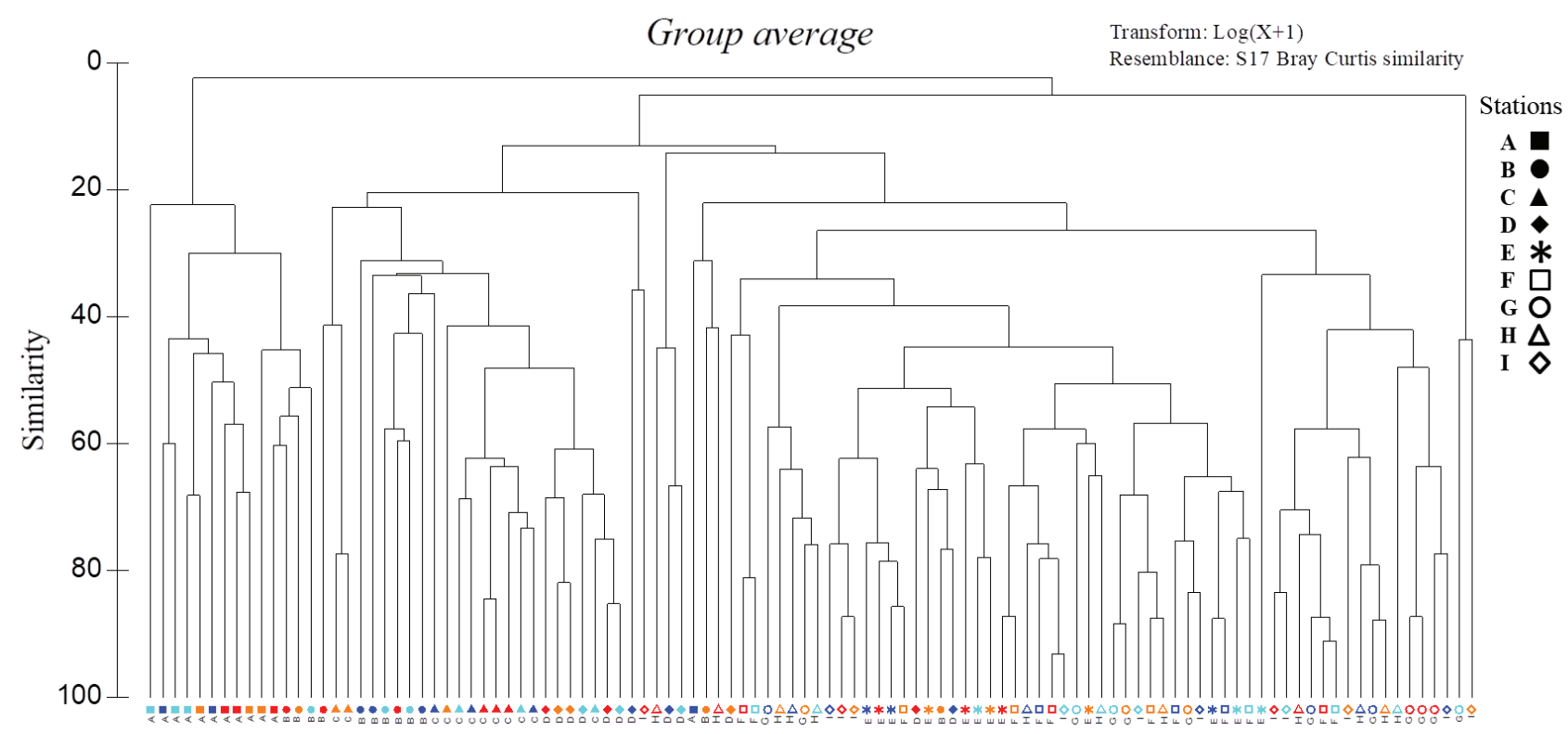

Samples

Figure 4. Cluster obtained by Bray Curtis similarity of mollusc assemblages of the investigated stations (A - I), each station at four sampling times, each time with three replicates (12 replicates for each station). Dark blue and red colours indicate the first two sampling seasons (W15 and S15 respectively); light heavenly and orange colours indicate the other two sampling seasons (W16 and S16 respectively)

analysis (Figure 5) the station-points were distributed with a notable continuity in the factorial space, so giving rise to a parabolic pattern (Guttman effect), which is spread from the negative portion of CAP1 (shallow station-points) to the positive (deep station-points) and reaches the inflection point ("apex" of the parable) in the positive portion of CAP2, where the station-points C and D of intermediate depths were plotted. Only few station-point replicates, too poorly structured, cannot take position in the frame of parabolic pattern and lay in the central area of the ordination model.

\section{Discussion}

The mollusc assemblage from the coastal area facing the Sarno River estuary is mostly characterized by the quantitative dominance of bivalves with species belonging to the order Lucinida (Lucinella divaricata, Thyasira biplicata, Axinulus alleni, Loripes orbiculatus), which are typically adapted to hypoxic or anoxic sediments for the presence of endosymbiotic sulphur bacteria (Southward, 1986; Dando and Southward, 1986; Anderson, 1995). Particularly the mollusc assemblage was clearly diversified along the bathymetric gradient, with a significant decrease in abun-

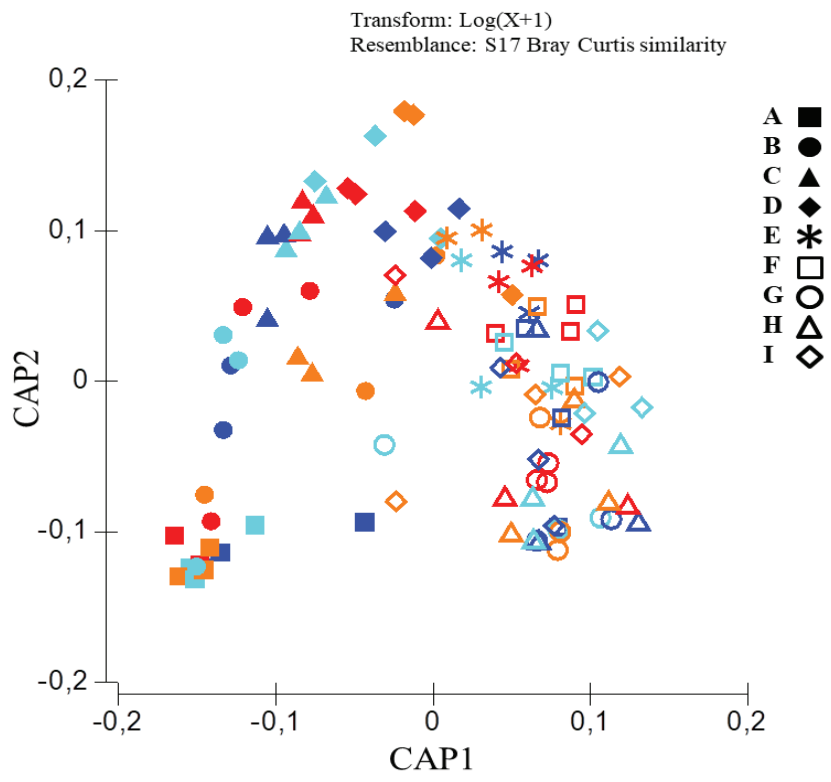

Figure 5. CAP plot showing spatial distribution of the stationpoints $(A-I)$, each with 12 replicates (3 replicates for 4 sampling times). Dark blue and red colours indicate the first two sampling seasons (W15 and S15 respectively), light heavenly and orange colours indicate the other two sampling seasons (W16 and S16 respectively) 
dance and species richness from coast to offshore. In addition, the structure of the mollusc assemblage along the depth gradient highlights a permanent coenocline (Whittaker, 1975), as clearly shown by the cluster analysis and the CAP ordination model, albeit with differences in the patterns related to gastropods and bivalves.

A distinct discontinuity emerged at about 20 meters depth along the coenocline of the gastropod assemblage resulting in a clear separation of two faunal assemblages. Thus, the abundance and the species richness was higher in the shallow area up to $20 \mathrm{~m}$ than in the deeper area from 20 to $95 \mathrm{~m}$, where very few gastropod species were found. Such a marked discontinuity might be explained with the model proposed by Pearson and Rosenberg (1978). In the investigated area, we coherently found sharp community structural changes occurring an along pollution gradient, with the most stressed areas inhabited by abundant populations of few pollution-tolerant opportunistic species. In the case of our study, we recorded only four abundant gastropod species, M. costulata, M. scabrida, B. nebula and T. varicosa in the shallower stations. The former three species are specialist carnivores, suggesting the occurrence in the soft bottom of abundant preys (mainly worms). The presence of the latter dominant species, the opportunistic scavenger T. varicosa, suggests the occurrence of dead or decaying organic matter and the presence of limiting conditions of eutrophication and hypoxia, to which it is tolerant (Riedel et al., 2012). Conversely, the deep stations were characterized by a scarce gastropod assemblage, mainly composed by species sensitive to organic enrichment, such as the dominant suspension feeder $T$. tricarinata and the detritus feeder $H$. vitrea (Borja et al., 2000), and by very few species of predators and ectoparasites.

Differently, the bivalves showed a quite gradual change in species composition from the shallow to the deeper stations, exhibiting an evident depth gradient. As opposed to the sharp discontinuity shown by the gastropods assemblage, in the bivalve assemblage a large transition area was evident, ranging between 20 and $30 \mathrm{~m}$ depth, where few species typical of the adjacent areas occurred. Such an "edge effect" is clearly demonstrated by the position of the station-points, corresponding to the transition area, at the apex of the parabolic pattern in the CAP ordination model. Similarly to the gastropods, also the bivalves include sensitive species tolerant to natural and human stressors, which are commonly used as indicators of environmental quality status (Costa et al., 2013; Dauvin et al., 2017; Donnarumma et al., 2018a; Klumpp and Burdon-Jones, 1982; Moraitis et al., 2018; Nerlović et al., 2011). In the shallow area, the suspension feeders $S$. subtruncata and $L$. divaricata were dominant. The former is characteristic of oxygenated sediments but is also tolerant, through physiological responses, to variations of organic matter content of the water column, even though a decrease of the Spisula population density and body-size in proximity of sewage outfalls is known in literature (Bouvy et al., 1989; de la Ossa Carretero et al., 2008; Pérès and Picard, 1964; Rueda and Smaal, 2002); indeed in our study it was dominant in summer when the effect of the Sarno river runoff is less intense. The latter species is typical of scarcely oxygenated sediments (Allen, 1958; Purchon, 1977; Taylor et al., 2011) and was dominant in winter, when the organic matter load from the river runoff was the highest level. The species composition of the assemblage of the intermediate transitional stations was mostly characterized by indicator species of sediment instability, such as Loripes orbicularis Poli, 1795, Nucula nitidosa Winckworth, 1930 and Corbula gibba (Olivi, 1792). Indeed, the first two species are considered sensitive to organic enrichment and the third one is an opportunistic, pollution-tolerant species (Borja et al., 2000; Gallmetzer et al., 2017; Hrs-Brenko, 2006; Moraitis et al., 2018). The dominance of the suspension feeding bivalves $T$. biplicata and A. alleni at the deeper stations also suggests the presence of high organic loads in the soft bottom transitional area, and is in agreement with the results reported by Keuning et al. (2011).

It is known that the deposit feeders are equipped with long inhalant siphons, through which they suck food particles from the sediment, even though they may switch their feeding mode from deposit to suspension feeding, in response to food availability in the water column (Dame 2016). For instance, this applies to the feeding behaviour of some deposit feeding bivalves, such as the nuculids $N$. nitidosa, Nucula sulcata Bronn, 1831 and the solemyoid Solemya togata (Poli, 1791), which are equipped with little siphons and feed ingesting sediment detritus by labial palps (Purchon, 1977; Zardus, 2002). Furthermore, this latter bivalve supplements its food supply through endosymbiotic sulphur bacteria, like other suspension feeders do, such as those belonging to the order Lucinida (Fisher, 1990; van Gils et al., 2012; Taylor et al., 2011). Finally, other noteworthy bivalves are the selective carnivores Cuspidaria spp. and Tropidomya abbreviate (Forbes, 1843), here reported as suspension feeders, which capture hyperbenthic plankton through their inhalant siphon (Morton and Machado, 2019; Reid and Reid, 1974).

Overall, the higher diversity, in terms of trophic guilds, is mostly ascribable to the presence of gastropod species recorded in the shallower stations. On the contrary, the dominance of the suspension feeding guild, occurred all along the depth gradient, is mostly due to bivalve species. These results are in agreement with the well-known association between feeding types and environmental variables, being the suspension feeders mainly recorded in areas subject to high hydrodynamic regime, whilst deposit feeders are dominant in the low-energy conditions where the particulate organic matter easily may reach the sea bottom (Dame, 2016; García-Arberas and Rallo, 2002; Pérès, 
1967; Pérès and Picard, 1964). In the present study, we suppose that the high amount of organic matter, transported by marine currents from the estuary to offshore, explains the marked abundance of suspension feeders recorded even at a considerable distance from the river mouth. This trend was also observed as rather constant over a temporal scale, both seasonally and annually. We can therefore conclude that in the coastal area facing the Sarno River mouth, the analysis of bathymetrical and temporal changes suggests the mollusc assemblages to be more affected by depth gradient than temporal variations, as it was highlighted by previous studies carried out on macrobenthos and meiobenthos communities in transitional water ecosystems (Foti et al., 2014; Semprucci et al., 2019). Finally, the scant literature concerning the ecological aspects of the study area makes our data of basic importance for improving the knowledge on macrobenthic biodiversity in a coastal area strongly exposed to continuous anthropogenic pressures. Our final considerations strengthen the requirement of planning appropriate and reliable environmental monitoring programs based, not only on transitory and ephemeral physico-chemical parameters of the water column, but also on the more conservative environmental matrix, such as the biological components of the sea-bottoms.

\section{References}

Allen J. A., 1958, On the basic form and adaptations to habitat in the Lucinacea (Eulamellibranchia). Philosophical Transactions of the Royal Society of London. Series B, Biological Sciences, 241(684), 421-484.

Anderson A. E., 1995, Metabolic Responses to Sulfur in Lucinid Bivalves. Amer. Zool., 35, 121-131.

Anderson M. J., Gorley R. N., Clarke K. R., 2008, PERMANOVA+ for PRIMER: Guide to Software and Statistical Methods. Plymouth.

Bevilacqua S., Sandulli R., Plicanti A., Terlizzi A., 2012, Taxonomic distinctness in Mediterranean marine nematodes and its relevance for environmental impact assessment. Marine pollution bulletin, 64, 1409-1416.

Boesch D. F., Wass M. L., Virnstein R. W., 1976, The dynamics of estuarine benthic communities. In Estuarine processes, Academic Press, pp. 177-196.

Borja A., Franco J., Pérez V., 2000, A marine biotic index to establish the ecological quality of soft-bottom benthos within European estuarine and coastal environments. Marine pollution bulletin, 40(12), 1100-1114.

Bouvy M., Soyer J., Cahet G., Descolas-Gros C., ThiriotQuiévreux C., Soyer-Gobillard M. O., 1989, Chemoautotrophic metabolism of intracellular gill bacteria in the marine bivalve Spisula subtruncata (da Costa). Netherlands Journal of Sea Research, 23(1), 29-34.
Buonocore E., Picone F., Russo G. F., \& Franzese P. P., 2018, The Scientific Research on Natural Capital: A Bibliometric Network Analysis. Journal of Environmental Accounting and Management, 6(4), 381-391.

Buonocore E., Picone F., Donnarumma L., Russo G. F., Franzese P. P., 2019, Modeling matter and energy flows in marine ecosystems using emergy and eco-exergy methods to account for natural capital value. Ecological Modelling, 392, 137-146.

Buonocore E., Donnarumma L., Appolloni L., Miccio A., Russo G. F., Franzese P. P., 2020a, Marine natural capital and ecosystem services: An environmental accounting model. Ecological Modelling, 424, 109029.

Buonocore E., Appolloni L., Russo G. F., Franzese, P. P., 2020 b, Assessing natural capital value in marine ecosystems through an environmental accounting model: A case study in Southern Italy. Ecological Modelling, 419, 108958.

Casoli E., Bonifazi A., Ardizzone G., Gravina M. F., Russo G. F., Sandulli R., Donnarumma L., 2019, Comparative Analysis of Mollusc Assemblages from Different Hard Bottom Habitats in the Central Tyrrhenian Sea. Diversity, 11(5), 74.

Cicchella D., Giaccio L., Lima A., Albanese S., Cosenza A., Civitillo D., De Vivo B., 2014, Assessment of the topsoil heavy metals pollution in the Sarno River basin, south Italy. Environmental earth sciences, 71(12), 5129-5143.

Clarke K. R., Gorley R. N., 2006, PRIMER v.6: User Manual/Tutorial. Plymouth.

Clarke K. R., Warwick R. M., 2001, Change in Marine Communities - an Approach to Statistical Analysis and Interpretation, 2nd Edn. Plymouth: Primer-E Ldt.

Costa P. M., Carreira S., Costa M. H., Caeiro S., 2013, Development of histopathological indices in a commercial marine bivalve (Ruditapes decussatus) to determine environmental quality. Aquatic toxicology, 126, 442-454.

Dame R. F., 2016, Ecology of Marine Bivalves: An Ecosystem Approach, 2nd ed.; CRC Press: Boca Raton, FL, USA; p. 283. ISBN 1439839123.

Dando P. R., Southward A. J., 1986, Chemoautotrophy in bivalve molluscs of the genus Thyasira. Journal of the Marine Biological Association of the United Kingdom, 66, 915-929.

Dauvin J. C., Bakalem A., Baffreau A., Delecrin C., Bellan G., Lardicci C., Balestri E., Sarda R., Grimes S., 2017, The well sorted fine sand community from the western Mediterranean Sea: A resistant and resilient marine habitat under diverse human pressures. Environmental pollution, 224, 336-351.

de la Ossa Carretero J. A., del Pilar Ruso Y., Casalduero F. G., Lizaso J. S., 2008, Effect of sewage discharge in Spisula subtruncata (da Costa 1778) populations. 
Archives of Environmental Contamination and Toxicology, 54(2), 226-235.

De Pippo T., Donadio C., Guida M., Petrosino C., 2006, The Case of Sarno River (Southern Italy). Effects of geomorphology on the environmental impacts (8pp). Environmental Science and Pollution Research - International, 13(3), 184-191. doi:10.1065/espr2005.08.287

Dimitriadis C., Koutsoubas D., 2008, Community properties of benthic molluses as indicators of environmental stress induced by organic enrichment. Journal of Natural History, 42(5-8), 559-574.

Donnarumma L., Sandulli R., Appolloni L., Russo G. F., 2018a, Assessing molluscs functional diversity within different coastal habitats of Mediterranean marine protected areas. Ecological Questions, 29(3), 35-51.

Donnarumma L., Sandulli R., Appolloni L., Sánchez-Lizaso J. L., Russo G. F., 2018b, Assessment of structural and functional diversity of mollusc assemblages within vermetid bioconstructions. Diversity, 10(3), 96.

Donnarumma L., Sandulli R., Appolloni L., Di Stefano F., Russo G. F., 2018c, Morpho-structural and ecological features of a shallow vermetid bioconstruction in the Tyrrhenian sea (Mediterranean Sea, Italy). Journal of Sea Research, 131, 61-68.

Edgar G. J., Barrett N. S., 2002, Benthic macrofauna in Tasmanian estuaries: scales of distribution and relationships with environmental variables. Journal of Experimental Marine Biology and Ecology, 270(1), 1-24.

Fisher C. R., 1990, Chemoautotrophic and methanotrophic symbioses in marine invertebrates. Reviews in Aquatic Sciences, 2, 399-436.

Fish J.D., Fish S. (1989) Mollusca. In: A Student's Guide to the Seashore, pp 183-281. Springer, Dordrecht.

Foti A., Fenzi G. A., Di Pippo F., Gravina M. F., Magni P., 2014, Testing the saprobity hypothesis in a Mediterranean lagoon: Effects of confinement and organic enrichment on benthic communities. Marine Environmental Research, 99, 85-94.

Gallmetzer I., Haselmair A., Tomašových A., Stachowitsch M., Zuschin M., 2017, Responses of molluscan communities to centuries of human impact in the northern Adriatic Sea. PLoS One, 12(7).

García-Arberas L., Rallo A., 2002, The intertidal soft-bottom infaunal macrobenthos in three Basque estuaries (Gulf of Biscay): a feeding guild approach. In Nutrients and eutrophication in estuaries and coastal waters (pp. 457-468). Springer, Dordrecht.

Griggs G. B., Johnson S., 1978, Bottom sediment contamination in the Bay of Naples, Italy. Marine Pollution Bulletin, 9(8), 208-214.

Herman P. M. J., Middelburg J. J., Van de Koppel J., Heip C. H. R., 1999, Ecology of estuarine macrobenthos. Advances in ecological research, 29, 195-240.
Hrs-Brenko M., 2006, The basket shell, Corbula gibba O1ivi, 1792 (Bivalve Mollusks) as a species resistant to environmental disturbances: A review. Acta Adriatica: international journal of Marine Sciences, 47(1), 49-64.

Hughes R. N., 1986, A Functional Biology of Marine Gastropods; Croom Helm: London, UK; Sydney, Australia, 1986; p. 245. ISBN 0709937466.

Jickells T. D., 1998, Nutrient biogeochemistry of the coastal zone. Science, 281(5374), 217-222.

Keuning R., Schander C., Kongsrud J. A., Willassen E., 2011, Ecology of twelve species of Thyasiridae (Mollusca: Bivalvia). Marine Pollution Bulletin, 62(4), 786791.

Klumpp D. W., Burdon-Jones C., 1982, Investigations of the potential of bivalve molluses as indicators of heavy metal levels in tropical marine waters. Marine and Freshwater Research, 33(2), 285-300.

Mannino A., Montagna P. A., 1997, Small-scale spatial variation of macrobenthic community structure. Estuaries, 20(1), 159-173.

Meade R. H., 1972, Transport and deposition of sediments in estuaries. In Environmental framework of coastal plain estuaries (Vol. 133, pp. 91-120). Geological Society of America Memoir.

Melluso G., Esposito A., Guida M., Maurano F., Trieff N. M., Pagano G., 1994, Distribution of inorganic and organic pollutants in river sediments in Campania, Italy. Bulletin of environmental contamination and toxicology, 52(1), 13-18.

Miller D. C., Muir C. L., Hauser O. A., 2002, Detrimental effects of sedimentation on marine benthos: what can be learned from natural processes and rates? Ecological Engineering, 19(3), 211-232.

Montuori P., Aurino S., Nardone A., Cirillo T., Triassi M., 2015, Spatial distribution and partitioning of organophosphates pesticide in water and sediment from Sarno River and Estuary, Southern Italy. Environmental Science and Pollution Research, 22(11), 8629-8642.

Montuori P., Cirillo T., Fasano E., Nardone A., Esposito F., Triassi M., 2014, Spatial distribution and partitioning of polychlorinated biphenyl and organochlorine pesticide in water and sediment from Sarno River and Estuary, Southern Italy. Environmental Science and Pollution Research, 21(7), 5023-5035.

Moraitis M. L., Tsikopoulou I., Geropoulos A., Dimitriou P. D., Papageorgiou N., Giannoulaki M., Valavanis V. D., Karakassis I., 2018, Molluscan indicator species and their potential use in ecological status assessment using species distribution modeling. Marine environmental research, 140, 10-17.

Morton B., Machado F. M., 2019, Predatory marine bivalves: A review. Advances in marine biology, 84, 1-98.

Nerlović V., Doğan A., Hrs-Brenko M., 2011, Response to oxygen deficiency (depletion): Bivalve assemblages 
as an indicator of ecosystem instability in the northern Adriatic Sea. Biologia, 66(6), 1114.

Pearson T. H., Rosenberg R. 1978, Macrobenthic succession in relation to organic enrichment and pollution of the marine environment. Oceanogr. Marine Biology Ann. Rev, 16, 229-311.

Pérès J. M. 1967, The Mediterranean benthos. Oceanogr. Marine Biology, 5: 449-533.

Péres J. M., Picard J., 1964, Nouveau manuel de bionomie benthique de la Mer Méditerranée: Rec. Trav. Station Marittime Endoume, 31(47), 137.

Purchon R. D. 1977, The Biology of the Mollusca. Second edition. Pergamon Press Ltd.

Reid R. G., Reid A. M., 1974, The carnivorous habit of members of the septibranch genus Cuspidaria (Mollusca: Bivalvia). Sarsia, 56(1), 47-56.

Riedel B., Zuschin M., Stachowitsch M., 2012, Tolerance of benthic macrofauna to hypoxia and anoxia in shallow coastal seas: a realistic scenario. Marine Ecology Progress Series, 458, 39-52.

Rueda J. L., Smaal A. C., 2002, Physiological response of Spisula subtruncata (da Costa, 1778) to different seston quantity and quality. In Nutrients and Eutrophication in Estuaries and Coastal Waters (pp. 505-511). Springer, Dordrecht.

Russo G. F., Fresi E., Scardi M., 1985, Il popolamento a Molluschi dei fondi mobili del Golfo di Salerno: analisi strutturale in rapporto al trofismo. Oebalia, 11(1), 339-348.

Russo G. F., Patti F., 2005, Early life history of two closely related gastropods, Rissoa auriscalpium and Rissoa italiensis (Caenogastropoda: Rissoidae). Marine Biology, 147, 429-437.

Semprucci F., Balsamo M., Appolloni L., Sandulli R., 2017, Assessment of ecological quality status along the Apulian coasts (Eastern Mediterranean Sea) based on meiobenthic and nematode assemblages. Marine Biodiversity, 48(1), 101-115.

Semprucci F., Facca C., Ferrigno F., Balsamo M., Sfriso A., Sandulli R., 2019, Biotic and abiotic factors affecting seasonal and spatial distribution of meiofauna and macrophytobenthos in transitional coastal waters. Estuarine, Coastal and Shelf Science, 219, 328-340.

Southward E. C., 1986, Gill symbionts in thyasirids and other bivalve molluscs. J. Mar. Biol. Ass. U.K., 66, 899-914.

Taylor J. D., Glover E. A., Smith L., Dyal P., Williams S. T., 2011, Molecular phylogeny and classification of the chemosymbiotic bivalve family Lucinidae (Mollusca: Bivalvia). Zoological Journal of the Linnean Society, 163(1), 15-49.

Teske P. R., Wooldridge T. H., 2003, What limits the distribution of subtidal macrobenthos in permanently open and temporarily open/closed South African estuaries? Salinity vs. sediment particle size. Estuarine, coastal and shelf science, 57(1-2), 225-238.

Urra J., Gofas S., Rueda J. L., Marina P., 2011, Molluscan assemblages in littoral soft bottoms of the Alboran Sea (Western Mediterranean Sea). Marine Biology Research, 7, 27-42.

van Gils J. A., van der Geest M., Jansen E. J., Govers L. L., de Fouw J., Piersma T., 2012, Trophic cascade induced by molluscivore predator alters pore-water biogeochemistry via competitive release of prey. Ecology, 93(5), 1143-1152.

Zardus J. D., 2002, Protobranch bivalves. Advances in marine biology, 42, 1-65.

Whittaker R. H., 1975, Community and Ecosystems. $2^{\text {nd }}$ edn. Macmillan, New York, USA.

WoRMS, 2020, World Register of Marine Species. https:// www.marinespecies.org at VLIZ. doi:10.14284/170 